\title{
A dinâmica da recepção: a intelectualidade brasileira e o ingresso do pensamento europeu do século XIX
}

\author{
Maxmiliano Martins Pinheiro \\ Recebido em setembro de 2020 \\ Aceito em dezembro de 2020
}

\section{RESUMO}

Este artigo apresenta uma discussão teórica sobre a sociologia pós-colonial e sua crítica ao pensamento eurocêntrico que procura obliterar a potencialidade científica dos países latino-americanos. Tendo como base a teoria social de Boaventura de Sousa Santos que se desdobra na defesa das "Epistemologias do Sul", o texto almeja dialogar com a tese defendida por Angela Alonso, posteriormente transformada em livro, que sustenta a dinamicidade da intelectualidade brasileira, no século XIX, durante a transição do período monárquico ao republicano, que concebeu nas matrizes do pensamento europeu, personificadas no liberalismo político e no positivismo, chaves para uma reconstrução sócio-política do Brasil. A partir disso, essa abordagem tem como pressupostos analisar a interação da sociologia pós-colonial de Sousa Santos com as de outros autores que ressaltam a problemática da condição pós-colonial em diferentes países e etnias, e em seguida, apresentar a análise histórica de Alonso, mediante o papel das elites intelectuais brasileiras, no processo de recepção das ideias européias, dialogando com a teoria de Sousa Santos.

Palavras-chave: eurocentrismo; intelectualidade brasileira; recepção.

\section{The dynamics of reception: Brazilian intellectuality and the admission of nineteenth-century European thought}

\begin{abstract}
This article introduces a theoretical discussion about postcolonial sociology and its criticism towards Eurocentric thought which endeavors to obliterate the scientific potentiality from Latin-American countries. Based on Boaventura de Sousa Santos' social theory that unfolds itself in the defense of "Epistemologies form South", this text aims at establishing a dialogue with Angela Alonso's thesis, which was subsequently transformed in a book, which supports the dynamics of Brazilian intellectuality, in the nineteenth century, during the transition from monarchical to republican period which envisages in the matrices form European thought, keys to reconstruct Brazilian social-politics. From this point, this approach has as assumptions analyzing the interaction between Sousa Santos' postcolonial sociology and other authors who stand out the problems from postcolonial condition in other countries and ethnicities, and thus, presenting the Alonso's historic analysis through the roles from Brazilian intellectual elites in the process of reception of European ideas in dialogue with Sousa Santos' theory.
\end{abstract}

Keywords: eurocentrismo; Brazilian intellectuality; reception.

\footnotetext{
${ }^{1}$ Mestrando em Sociologia Política pela UCAM/IUPERJ. Mestre em Literaturas de Língua Inglesa pela UERJ. Especialista em Sociologia, Política e Cultura pela PUC-Rio. Especialista em Literaturas de Língua Inglesa pela UERJ. Contato: martinsmaxmiliano783@gmail.com.
} 


\section{Introdução}

As teorias pós-coloniais repousam basicamente no mapeamento de centro e periferia, uma vez que a semiótica dessa cartografia como expressão e efetuação de formas do domínio colonial confere uma grande importância à questão do espaço conceitual imaginado na esfera política. Portanto, a sociologia pós-colonial não se preocupa somente com o poder bruto de uma nação colonizadora sobre as demais colonizadas, mas principalmente com o funcionamento do poder representativo que o centro colonizador engendra na linguagem e nas imagens coloniais, assim como a maneira que as periferias reagem a esses agentes externos de opressão.

Considerando as observações acima, esse estudo tem como objetivo central estabelecer um diálogo entre o artigo de Boaventura de Sousa Santos, intitulado "Para além do Pensamento Abissal: das linhas globais a uma ecologia dos saberes" com a obra de Angela Alonso, Idéias em Movimento: A Geração 1870 na Crise do Brasil-Império, procurando analisar a postura epistemológica da intelectualidade brasileira que, embora não tendo erigido um sistema de pensamento próprio como meio de emancipação, utilizou o pensamento europeu como instrumento de auto-gestão social e política conferindo-lhe um sentido particular. Para atingir esse objetivo, nossa abordagem está estruturada em dois tópicos propiciando um devido desdobramento: primeiramente, será analisada a teoria pós-colonial de Boaventura de Sousa Santos a respeito das chamadas "Epistemologias do Sul" que tem como relevo a potencialidade científica dos países latino-americanos que foram vítimas do pensamento "abissal" articulado pelo domínio europeu que anulava completamente a capacidade dos povos latinos em elaborar um saber próprio como empoderamento, mantendo-os na subalternidade. Com isso, será ressaltado como a visão sociológica de Sousa Santos interage com as de outras vozes que abordaram a problemática da condição pós-colonial, tais como Edward Said, Frantz Fanon, entre outros.

Em seguida, será abordada a análise histórica de Angela Alonso que, focalizando a crise do regime monárquico e a ascensão da República no Brasil, procura mostrar o 
quanto as elites intelectuais concebiam as correntes de pensamento do século XIX, em particular o liberalismo político e o positivismo, como instrumentos auxiliares de modernização nacional, efetuando contornos e modificações de acordo com a realidade brasileira. Por fim, será proposto como conclusão, conforme sugere o título do trabalho, que a nossa sociedade desvela no exercício da sua intelectualidade, conforme a experiência histórica no final do século XIX, uma inclinação singularmente pragmática do conhecimento, pois mesmo não elaborando um sistema de pensamento próprio, consegue adaptar engenhosamente correntes filosóficas alheias como veículos de autoregulação social e gerenciamento desenvolvimentista.

\section{A teoria de Boaventura de Sousa Santos e a sociologia pós-colonial contemporânea}

Adentrando a teoria pós-colonial de Boaventura de Sousa Santos, abordaremos dois aspectos norteadores segundo a qual ela se estrutura: o denominado "pensamento abissal" que ilustra a estratégica empreendida pelo pensamento moderno eurocêntrico que coloca na inexistência e na invisibilidade tudo que se encontra fora do grande Ocidente, e o que ele considera como "pensamento pós-abissal" que compreende a tentativa dos países latino-americanos em erigir um pensamento não-derivativo, ou melhor, uma ruptura radical com as manifestações ocidentais modernas de raciocínio e ação. Para Sousa Santos (2009), o pensamento abissal, expressão da modernidade ocidental, configura em um sistema de distinções visíveis e invisíveis, sendo que estas últimas existem em função das primeiras. Há fronteiras solidamente estabelecidas que fragmentam a realidade social em dois lugares diferenciados, a saber: o horizonte "deste lado da linha" e o horizonte "do outro lado da linha":

A divisão é tal que 'o outro lado da linha' desaparece enquanto realidade, tornase inexistente, e é mesmo produzido como inexistente. Inexistência significa não existir sob qualquer forma de ser relevante ou compreensível. Tudo aquilo que é produzido como inexistente é excluído de forma radical porque permanece exterior ao universo que a própria concepção de inclusão considera como sendo o Outro. A característica fundamental do pensamento abissal é a impossibilidade da co-presença dos dois lados da linha. Este lado da linha só prevalece na medida em que se esgota o campo da realidade relevante. Para 
além dela há apenas inexistência, invisibilidade e ausência não-dialética. Para dar um exemplo baseado no meu próprio trabalho, tenho vindo a caracterizara modernidade ocidental como um paradigma fundado na tensão entre a regulação e a emancipação social. Esta distinção visível fundamenta todos os conflitos modernos, tanto no relativo a fatos substantivos como no plano dos procedimentos (SANTOS, 2009).

Pode-se inferir que o pensamento abissal enrijece uma linha divisória flagrantemente arbitrária que distancia tudo aquilo que é concebido como invisível, irrelevante, inexistente, daquilo que é visto como relevante e verdadeiro, posto que dessa forma o pensamento ocidental moderno logrou em colocar na inferioridade todas as manifestações filosóficas e culturais oriundas dos povos colonizados, inviabilizando assim não apenas o diálogo, mas também qualquer olhar igualitário. Como bem assevera Homi Bhabha (1992), a narrativa ocidental engendrou um aparato discursivo que produz o colonizado numa realidade fixa, por meio de um sistema de representação que estruturalmente se assemelha ao realismo, com signos que indicam uma totalidade reformada e reconhecível. Desse modo, discurso colonial reconhece e nega as diferenças raciais, culturais e históricas dos colonizados, criando um espaço para as "subjetividades das pessoas”, isto é, para os “outros” subalternizados, através da produção de conhecimentos para exercer vigilância e domesticação sobre esses sujeitos. Ao sublinhar a investida do pensamento eurocêntrico que assevera a inexistência desse Outro como uma realidade incapaz de produzir capital científico e cultural, a sociologia de Sousa Santos encontra uma simetria com a análise de Edward Said (2019) quando este salienta que o "Orientalismo" configura um discurso que, ao longo dos séculos, tem-se feito considerável investimento material, isto é, algo que o torna um sistema de conhecimento sobre o Oriente, uma malha intelectual consentida para filtrar o Oriente na consciência ocidental.

Com efeito, o Oriente com sua imagem exteriorizada auxiliou a definir o Ocidente tornando-se parte integrante da cultura material europeia que logrou em exercer o seu domínio discursivo na ação colonialista (SAID, 2019). Desse modo, o Orientalismo ilustra uma extensão ou faceta da moderna cultura político-intelectual empreendida pelo Ocidente, logo tem menos a ver com a realidade oriental do que o mundo ocidental (SAID, 2019). É propício acrescentar aqui uma observação de Frantz 
Fanon (2008) que, ao analisar a condição do negro sob o prisma pós-colonial, afirma que a inferiorização que o colonizado imputa em si mesmo é o "correlato nativo da superiorização européia”, pois o agente racista cria o indivíduo inferiorizado. Enquanto o branco retira do negro qualquer valor ou originalidade, o negro, por sua vez, procura fazer-se branco como meio de adquirir reconhecimento no lugar de lutar pela sua voz (FANON, 2008). Em síntese, o pensamento sociológico de Sousa Santos interage com as teorias pós-coloniais contemporâneas uma vez que ressalta a impossibilidade das sociedades que foram impedidas em exprimir suas vozes em contraposição ao poder cultural investido do Ocidente.

Dissecando o confinamento que o pensamento abissal eurocêntrico imputa aos povos subalternizados, Sousa Santos (2009) ressalta o quanto o conhecimento científico e o direito moderno expressam o domínio cultural desse pensamento. Sendo assim, eles representam as duas principais linhas abissais globalizantes dos tempos modernos, mesmo operando de forma diferenciada. Com efeito, cada uma erige uma lógica de distinções visíveis e invisíveis em que estas últimas fundamentam a existência das primeiras. No que tange ao conhecimento, o pensamento abissal atribui à ciência moderna o status de legitimar universalmente o que é considerado verdadeiro ou falso. Por conseguinte, as sociedades eurocêntricas produzem a validade universal da ciência moderna baseada nos fatos e na observação, enquanto as nações “do outro lado da linha”, presas na teologia e na metafísica, não constroem conhecimento real, apenas crenças, opiniões, magia, idolatria, entendimentos intuitivos (SANTOS, 2009). Quanto ao direito, "este lado da linha" o legitima como aquilo que é legal ou ilegal segundo os paradigmas do direito oficial do Estado moderno. Portanto, o território "do outro lado da linha” onde não é reconhecida sua capacidade de construir seu sistema jurídico próprio é um espaço sem lei, ou seja, o local do a-legal ou ilegal, de acordo com direitos não oficialmente legitimados (SANTOS, 2009).

Edward Said (2019) assevera a forte influência que a Grã-Bretanha, a França e, mais tarde a Alemanha e os EUA, exerceram sobre os estudos orientais a ponto de essas nações consolidarem uma espécie de autoridade intelectual sobre o Oriente inserido na cultura ocidental. Por essa razão, além de vedar aos povos subalternizados a possibilidade de construção do saber científico e do direito institucional, nega-se 
também a perspectiva desses povos em erigir as próprias narrativas conforme suas experiências históricas. Trata-se, segundo Steven Connor (200o), de um "imperialismo de representação" onde a prevalência da narrativa universal projeta imagens fetichizadas não só dos países orientais como da África Ocidental, da América Latina e de outras regiões vistas como subalternas, conforme a óptica dos centros ocidentais que silencia quaisquer tentativas de auto-representação desses povos. Por isso, as teorias póscoloniais procuram franquear as analises discursivas às vozes daqueles rotulados como o Outro, controlando as linguagens, metáforas e símbolos utilizados para emudecer aqueles a quem pretendem personificar na representação (CONNOR, 200o). O radicalismo do pensamento abissal conduz a lógica da apropriação e violência nos domínios sociais "do outro lado da linha" a lidar com os indivíduos como "não-cidadãos" ou "selvagens coloniais" de acordo com a engrenagem do fascismo social que faz com que o Estado de exceção interaja com a normalidade constitucional já que este tipo de fascismo coexiste até mesmo com a democracia liberal (SANTOS, 2009).

Reagindo à investida do pensamento abissal, a mentalidade pós-abissal constata que o fenômeno da exclusão assume diferentes figurações conforme é prescrito por uma linha abissal ou pós-abissal, sendo que, enquanto a exclusão abissal afincar, as possibilidades de uma alternativa pós-capitalista e inclusiva serão sempre rechaçadas. Por isso, reconhecer a exclusão abissal com suas facetas sinaliza uma meta que só será efetuada durante um extensivo período de transição. Para Sousa Santos, deve-se perceber a solidez do pensamento abissal para que se possa pensar em uma alternativa diferente, pois sem esta constatação a mentalidade crítica só produzirá reiterações das linhas abissais:

O reconhecimento da persistência do pensamento abissal é, assim, a conditio sine qua non para começar a pensar e a agir para além dele. Sem este reconhecimento, o pensamento crítico permanecerá um pensamento derivativo que continuará a reproduzir as linhas abissais, por mais anti-abissal que se autoproclame. Pelo contrário, o pensamento pós-abissal é um pensamento não derivativo, envolve uma ruptura radical com as formas ocidentais modernas de pensamento e ação. No nosso tempo, pensar em termos não-derivativos significa pensar a partir da perspectiva do outro lado da linha, precisamente por o outro lado da linha ser o domínio do impensável na modernidade ocidental. A emergência do ordenamento da apropriação/violência só poderá ser enfrentada se situarmos a nossa perspectiva epistemológica na experiência social do outro lado da linha, isto é, do Sul global não-imperial, concebido como 
metáfora do sofrimento humano sistêmico e injusto provocado pelo capitalismo global e pelo colonialismo. O pensamento pós-abissal pode ser sumariado como um aprender com o Sul usando uma epistemologia do Sul. Confronta a monocultura da ciência moderna com uma ecologia de saberes. É uma ecologia, Porque se baseia no reconhecimento da pluralidade e conhecimentos heterogêneos e em interações sustentáveis e dinâmicas entre eles sem comprometer a sua autonomia (SANTOS, 2009).

De acordo com o trecho acima, o pensamento pós-abissal é uma tomada de consciência dos povos subalternizados que rompe radicalmente com as manifestações filosóficas da modernidade e assume uma epistemologia própria, denominada “epistemologia do Sul” em que toda produção do pensamento é erigida sob o prisma "do outro lado da linha" que durante séculos foi classificado como o território da ausência do saber e do conhecimento científico. Só desse modo que as sociedades da América do Sul poderão enfrentar a apropriação violenta imposta pelo colonialismo e pelo capitalismo se elas conceberem suas próprias perspectivas epistemológicas conforme as experiências sociais e históricas. A epistemologia do Sul entra em cena como uma contraposição ao domínio da ciência moderna através de uma ecologia de saberes que repousa na pluralidade dos conhecimentos heterogêneos.

Quanto à ecologia dos saberes, o autor assegura que esta é uma contraepistemologia universal impulsionada por dois fatores: o primeiro é o surgimento político de povos e concepções do mundo “do outro lado da linha” que em conjunto se contrapõem ao capitalismo global. O segundo baseia-se na multiplicação de alternativas que não podem ser associadas sob a competência de uma única perspectiva global, o que propicia o exercício da ecologia dos saberes no intuito de investir consistentemente no pensamento pluralista e propositivo (SANTOS, 2009). Por rejeitar a defesa de uma perspectiva centralizadora no singular, a teoria pós-colonial de Sousa Santos demonstra suspeitas perante aos modelos binários que, articulando as margens, demandam a eclosão de uma fala e de uma identidade plenas (CONNOR, 200o). Tal rejeição ao binarismo é sustentada pela análise Stuart Hall (2009), embora explore outras questões vinculadas à etnia e à diáspora, quando assevera que qualquer defesa de uma etnicidade absoluta, que sublima os valores distintivos de uma comunidade local sem diálogo com outros valores, essencializa sobremaneira a diferença cultural, fixando assim binarismos raciais ou culturais que conduzem ao fechamento e ao congelamento histórico. 
No entanto, existem teorias pós-coloniais que desacreditam na emancipação do ente subalternizado. A pesquisa de Gayatri Spivak (2010), por exemplo, analisando a condição do povo indiano, seu lugar de origem, afirma primeiramente a existência de uma violência epistêmica como um projeto remotamente articulado e heterogêneo que efetua a obliteração assimétrica dos vestígios do Outro em sua precária subjetividade. Tal violência epistêmica orquestrada pelo imperialismo oferece somente uma vaga ideia da violência geral que é a possibilidade de uma escritura (SPIVAK, 2010). Sem adentramos nessa discussão, a conclusão de Sousa Santos a respeito da ecologia dos saberes nos parece muito plausível não só por sua sociologia ter sido elaborada décadas após o estudo de Spivak, mas principalmente por legitimar a atuação de diversas alternativas livres do confinamento de uma única diretriz uniforme e globalizadora.

\section{As ideias europeias em movimento no Brasil do século XIX}

Nesta segunda parte, abordaremos o processo de incorporação das perspectivas filosóficas européias do século XIX como forma de emancipação política empreendido pela sociedade brasileira através da geração de 1870 durante a crise da monarquia e a ascensão do regime republicano. Trata-se de uma tarefa delicada uma vez que Boaventura de Sousa Santos (2009) destaca o liberalismo político e particularmente o positivismo, como expressões do pensamento abissal, e a própria Angela Alonso (2002), no seu livro selecionado para análise, sublinha que o intercâmbio do movimento intelectual dessa geração com o repertório europeu não se consagrou visando a construção de teorias nativas ou sistemas teóricos porque as ideias européias serviram mais como recursos intelectuais acionados de acordo com as necessidades dos agentes na arena política. Todavia, a autora ressalva que o movimento intelectual da geração 1870 não recorreu ao mero ingresso do pensamento europeu. Com efeito, parte dessa geração efetuou uma ressignificação nos esquemas de pensamento cristalizados como tradição nacional, atribuindo-lhes novas formas de ação política coletiva (ALONSO, 2002). É sobre este dinamismo que a intelectualidade brasileira logrou na recepção do liberalismo político e do positivismo como veículos de modernização nacional que este tópico se embasa. Por isso, torna-se necessário examinar o impulso contestador dos 
liberais e dos positivistas à ordem imperial vigente no final do século XIX, e como emergiram as propostas políticas modernizadoras por meio do contato da intelectualidade brasileira representada por esses grupos com as referidas vertentes do pensamento europeu.

Toda ação do movimento da geração 1870 decorreu da exclusão política de grupos sociais devido à dominação da elite saquarema² durante o Segundo Reinado. Para Angela Alonso (2002), o ponto de interseção entre segmentos tão diferenciados era a experiência compartilhada de marginalização política que acarretava no impedimento ao ingresso das instituições políticas fundamentais, uma vez que esses grupos estavam alijados pelo status quo saquarema.

Por conseguinte, esse movimento foi uma resposta coletiva de grupos sociais que se configurou na produção de escritos e associações intelectuais, visando uma forte crítica às instituições políticas do Segundo Reinado e aos valores da tradição imperial. Foram realizados debates públicos tendo como base um novo repertório intelectual que propiciava a esses segmentos uma compreensão crítica da conjuntura brasileira no final do século XIX e armas para a luta política. Sendo assim, a adoção de teorias científicas e liberais durante a crise do império pode ser redefinida como um movimento políticointelectual de refutação constituído por grupos sociais díspares em origem social, mas consensuais em seus objetivos, já que se encontravam politicamente marginalizados (ALONSO, 2002).

Dessa forma, podemos constatar que essa reação coletiva à ingerência da elite saquarema na monarquia desvela, em certo grau, um caráter pragmático já que as instituições políticas não propiciavam uma participação política efetiva desses grupos que constituíam um movimento de elite. Cumpre ressaltar que os movimentos intelectuais brasileiros do século XIX eram essencialmente elitizados uma vez que seus membros tinham acesso ao ensino superior, em uma sociedade em que o diploma sendo um recurso demasiadamente escasso simbolizava status e possibilidade de carreira pública. Por outro lado, podemos igualmente perceber que esses mesmos segmentos

\footnotetext{
2 Segundo Ilmar Rohloff de Barros (2004): "A elite saquarema era uma classe senhorial que englobava, durante o Segundo Reinado, a alta burocracia imperial composta por senadores, magistrados, ministros, conselheiros do Estado e parte do clero, assim como proprietários rurais de diversas regiões que sustentavam o poder vigente, por meio dos princípios da ordem e da civilização.
} 
nutriam uma forte disposição de reformar o Brasil diante da conjuntura da crise do Império adotando em contrapartida novas ideias científicas e políticas. Por conseguinte, o movimento intelectual da geração 1870 tem como repertório intelectual o liberalismo político e o positivismo com suas ramificações heterodoxas - evolucionismo spenceriano, darwinismo e monismo - em detrimento da política da Corte.

Essas linhagens de oposição e de radicalização à dominação saquarema durante o período imperial tinham caráter heterogêneo. Segundo Alonso (2002), as dissidências liberais nasceram no bojo da elite imperial e de segmentos tradicionalmente incorporados pela lógica estamental dos negócios do Império. Havia vínculos entre esses novos liberais com o antigo Partido Liberal. Os maiores representantes desse grupo foram Quintino Bocaiúva e Joaquim Nabuco. Por essas razões, a marginalização desse grupo é de caráter estritamente político considerando que suas prerrogativas políticas encontravam-se suspensas por causa da ordem conservadora vigente. Com efeito, a marginalização política desse grupo não significava exclusão social uma vez que essa mocidade liberal gozava do acesso a certos cargos burocráticos e negócios. Nesse sentido, eles tinham liberdade do desenvolvimento de suas carreiras, mas não de ocupar postos de comando do regime (ALONSO, 2002).

No caso das associações positivistas, a ampliação da entrada no sistema de ensino superior, com a reforma de 1874, propiciou o acesso para jovens de condição financeira intermediária e até mesmo para segmentos sociais que se encontravam marginalizados em relação à economia escravista, rompendo assim com a homogeneidade das classes privilegiadas no meio acadêmico. Portanto, as escolas superiores possibilitaram seus espaços públicos para grupos sociais que até o momento não tinham expressão sócio-política (ALONSO, 2002). Porém, a expansão de postos de trabalho de acordo com a burocracia do Estado não foi suficiente para abarcar todos os novos diplomados, pois a oferta dos novos cargos públicos foi decaindo. Além disso, não houve crescimento do ingresso da carreira política e a lógica estamental de apadrinhamento engendrada pelos chefes partidários e da Corte era mantida (ALONSO, 2002). Enfim, os segmentos liberais e positivistas enfrentaram diferentes gêneros de marginalização em relação ao domínio saquarema de poder na monarquia. Sejam eles 
de caráter político, social ou econômico, esses grupos assimilaram a mesma insatisfação com um regime estacionário que não se modernizava.

Por esses motivos, a geração 1870 se afastava da tradição político-intelectual do Segundo Reinado gerindo um arcabouço intelectual heterogêneo conforme as vertentes de pensamento que cada grupo adotava, atendendo à urgência de constituir identidade própria. Daí adotarem os nomes de "novos liberais”, “igreja positivista”, “abolicionistas”, “comteanos", "darwinistas", entre outros. Alonso (2002) conclui que os grupos da geração 1870 que se mobilizaram não tinham como meta um pensamento doutrinário comum porque não primavam criar escolas nativas de pensamento. De fato, seus interesses por novas teorias na crise monárquica podem ser definidos como um movimento político-intelectual de contestação, formado por segmentos sociais bem distintos, mas experimentando uma unidade de sentido. Roque Spencer Maciel de Barros (1986) afirma que as filosofias progressistas da história, consubstanciadas em teorias evolutivas como a "lei dos três estados" do positivismo comteano, motivaram os liberais e cientificistas independentes, pois apontavam o futuro nacional em simetria com o futuro universal, contrabalanceando o pessimismo resultante da análise da conjuntura brasileira. Em suma, a adoção dessas linhas do pensamento abissal, valendose dos termos de Sousa Santos, como meio de contestação ao Império brasileiro, deparou-se com a realidade contrastante assentada em diferenciações entre grupos vindos de uma enorme variedade de estratos sociais, assim como múltiplas manifestações intelectuais que concebiam tanto o liberalismo quanto o positivismo conforme suas formações intelectuais, mas que lograram consenso crítico.

Liberalismo político e positivismo possibilitaram um sólido repertório políticointelectual para que as elites brasileiras pudessem efetivar reformas sociais modernizadoras em contraposição ao legado sócio-econômico da estrutura imperial. Analisando o problema da escravidão, Maria Thereza Rosa Ribeiro (2012) ressalta que tanto o pensamento liberal de Joaquim Nabuco como o positivismo comteano de Miguel Lemos e Raimundo Teixeira Mendes, enveredou para o clímax emblemático “ou progresso, ou escravidão" incomodando a hegemonia do discurso escravista da época através da discussão de propostas a fim de reorganizar a sociedade brasileira. A crítica dos liberais e positivistas que apontava o estatuto do cidadão livre conquistou 
legitimidade por estar imbuída das expressões da "razão e justiça” ou "ciência” oriundas da mentalidade européia. É importante inserir as observações de Florestan Fernandes sobre a escravidão. Para esse autor, ao longo da segunda metade do século XIX, a sociedade brasileira passa por um processo de desagregação do regime servil. Dessa forma, a escravatura gradativamente desaparece por causas das novas condições de existência social. Tal dissolução do regime servil se desdobra desde o fim do tráfico africano, em 1850, até a abolição da escravatura, em 1888, atravessando quatro décadas, até chegar à década de 1880, em que a agitação abolicionista atinge as senzalas e as camadas populares, propiciando ao próprio escravo, uma ação decisiva no solapamento do sistema laboral vigente, por meio de fugas em massa que desarticulavam os trabalhos nas fazendas (FERNANDES, 2008). Com isso, pode-se compreender a necessidade dos liberais e dos positivistas em pleitear projetos sociais reformistas que respondessem à crise que se encontrava o regime de trabalho no Brasil no final do século XIX.

Cumpre primeiramente elucidar que o pensamento abissal, nas palavras de Boaventura de Sousa Santos (2009), mostra-se capaz de produzir e radicalizar distinções que por mais drásticos que sejam os resultados elas são produto de uma mentalidade ocidental "deste lado da linha”. Por isso, devemos ter em mente que tanto o liberalismo quanto o positivismo, apesar de serem manifestações da mentalidade eurocêntrica, não desejam a perene subalternidade dos povos "do outro lado da linha". Antonio Paim (1987) assevera a conotação antimonárquica e libertária do liberalismo brasileiro, durante a inconfidência mineira, mesmo esse estando bem distanciado dos propósitos maiores do pensamento liberal; assim como as intenções igualitárias atribuídas à revolução baiana contra as autoridades da época. Ivan Monteiro de Barros Lins (1967) destaca a repercussão que o positivismo difuso exerceu no Brasil consoante suas manifestações de uma política internacional anticolonialista propugnando os princípios da não-intervenção e da autodeterminação dos povos. Basta lembrar que, segundo Augusto Comte, todas as nações atravessam a lei dos três estados em fases sucessivas (teológica/militar, metafísica/jurídica e científica/industrial) alcançando suas autonomias efetivas. O que a sociologia de Sousa Santos reivindica através de uma ecologia de saberes é a possibilidade de a América Latina encontrar sua própria autonomia por meio de uma contra-epistemologia universal baseada na 
heterogeneidade de conhecimentos e experiências variadas e oriundas de seus povos, tornando o pensamento liberal, o positivismo e o próprio marxismo exemplos de ilusões ocidentais.

Examinando o legado do liberalismo político e do positivismo não adentraremos na seara que os intelectuais brasileiros da geração 1870 assimilaram dessas vertentes. Serão observadas então as linhas gerais que cada uma dessas matrizes propugnou. De início, cumpre reiterar a asserção que a produção intelectual dessa geração elaborou programas reformistas não conforme a adesão a doutrinas estrangeiras, uma vez que seu repertório científico ou político não repousava na conjunção de autores e teorias, mas na capacidade de clarificar a conjuntura brasileira e gerir novos meios de ação política (ALONSO, 2002).

O liberalismo político emergente no Brasil no final do século XIX se diferenciava do liberalismo imperial, sobretudo quanto à interpretação de uma comunidade de iguais. Para o velho liberalismo, uma comunidade de iguais era constituído por famílias, com prerrogativas ilustradas numa figura representativa, enquanto para o novo, a célula da modernização social é o indivíduo que compõe um povo livre. Para isso torna-se essencial generalizar direitos individuais (ALONSO, 2002). Sendo assim, o novo liberalismo enseja a formação de um regime político baseado na liberdade individual, tolerância, universalização de direitos e extensão da cidadania como percurso organicista da evolução de uma sociedade:

É a partir de uma teoria organicista da evolução das sociedades que a crítica à exclusão de uma fração da população da arena das decisões políticas se constrói. Os africanos e seus descendentes seriam indivíduos, aos quais caberia, conceder direitos. A extensão da cidadania a ex-escravos só faz sentido quando se concebe a universalização de direitos, o que era literalmente impensável segundo os esquemas mentais da tradição imperial. Há aqui uma transição entre uma maneira aristocrática e outra democrática de conceber a distribuição de poder político. A democracia não exprime mais seu sentido setecentista, de república. Para os novos liberais tem já o sentido moderno, de garantia de liberdades individuais e de participação política ampliada: "lei da democracia vem a ser: ninguém tem o direito de acertar por ele e impor-lhe seu critério" (ALONSO, 2002).

Como se observa, os novos liberais apostavam na superação de uma mentalidade política aristocrática em prol de outra democrática arraigada na extensão da cidadania 
a todos os indivíduos que passam a ser vistos como cidadãos segundo a universalização dos direitos até então desconhecida pela tradição imperial. Nota-se assim uma profunda ingerência do contratualismo europeu nessa prerrogativa democrática. Ribeiro (2012) analisa o liberalismo político de Nabuco como uma perspectiva política de viés democrático, propagado por uma nova elite intelectual que assumia de forma consistente um renovado repertório de opinião pública na defesa de uma cidadania ampliada, do sufrágio universal e dos partidos políticos. Tal crédito ao liberalismo como rumo para civilização moderna acarretava prerrogativas de modernização econômica e descentralização administrativa. Na verdade, alguns liberais do período monárquico já supunham que o liberalismo econômico pudesse exercer funções normativas, devendo resultar de sua influência soluções para o problema institucional (PAIM, 1987). A nova geração liberal concebia o modelo estadunidense como trajetória econômica a ser trilhada onde a descentralização da política, do Estado e dos negócios surgiria como princípio norteador. Além da cidadania plena num regime de liberdades públicas, haveria divisão do trabalho e imigração proletária de chineses patrocinada pelo Estado (ALONSO, 2002). Defendeu-se também a criação do imposto territorial rural e o fim dos incentivos fiscais e das linhas de credito ao latifúndio considerado improdutivo. Enfim, um americanismo restrito ao liberalismo econômico e à lei de terras (ALONSO, 2002). Com isso, observa-se que o liberalismo advogado pela geração 1870 revelava maiores preocupações de ordem política apesar de defender questões sociais como o trabalho livre. O grande entrave deixado pelo legado liberal foi essa confiança desmedida no modelo estadunidense como parâmetro nacional-desenvolvimentista, estreitando a criação de um projeto nacionalista no Brasil.

Já o positivismo, por sua vez, compreendia a questão social como uma prerrogativa bem mais importante que a reforma política. Por conseguinte, o cerne do reformismo social empreendido pelos positivistas da geração 1870 reside na luta pela inclusão social dos setores mais periféricos do sistema imperial, isto é, os negros, na condição de ex-escravos e cidadãos. Alonso ressalta que o núcleo de pauta de reformas deste grupo, principalmente os positivistas ligados ou relacionados com a Religião da Humanidade, é a causa escravista. Enquanto as dissidências heterodoxas procuraram compensar o fim da escravidão, positivistas abolicionistas como Miguel Lemos e Teixeira 
Mendes, por exemplo, eram peremptórios na tarefa de extinguir definitivamente a escravidão negando o direito à indenização aos grandes proprietários (ALONSO, 2002). Para os positivistas ortodoxos era o negro que tinha verdadeiramente esse direito por ter sido desumanizado durante séculos. Assim sendo, a dimensão crítica do discurso positivista assume um cunho essencialmente moral. Seus argumentos sublinhavam que a escravidão foi degradante tanto para o escravo violentado como para o senhor que se apropriou do produto do trabalho de indivíduos que não vieram da sociedade brasileira (ALONSO, 2002). Sendo a escravidão moderna um sintoma de retrocesso social comparada com a escravidão antiga, os positivistas constaram que a abolição em si não resolveria o problema social dos negros que constituíam a maioria da população brasileira e propuseram um amplo projeto de proteção social:

\begin{abstract}
Para os positivistas abolicionistas, a abolição era o ponto cardeal. Mas a "marcha da civilização" apontava para o futuro industrialista. O capitalismo aparecia como fatalidade. A divisão do trabalho geraria "inevitavelmente uma sociedade de classes". Com o regime escravista cairia todo o sistema de produção agrícola nele esteado. Por isso, a reforma agrária não geraria eficiência econômica. $\mathrm{Na}$ passagem para a sociedade "urbano-industrial" ocorreria a metamorfose do escravo em operário. Moralmente a mercantilização do trabalho sob o capitalismo não diferia substantivamente da desumanização do escravismo, pela coisificação da pessoa. Transportado do campo à cidade, do cativeiro à liberdade, o ex-escravo ficaria a mercê das forças disruptivas do mercado. Aí estava a raiz do "conflito social moderno". Para evitá-lo, os positivistas abolicionistas recuperaram, à maneira do liberalismo imperial, princípios tradicionais de solidariedade e hierarquia. O corolário indispensável da abolição seria uma espécie de previdência social. A hierarquia de funções sociais e a expropriação do trabalho deveriam ser compensadas por um conjunto de proteções sociais para o proletário. A ênfase estava nos deveres sociais do patriciado em vez dos direitos políticos do proletariado: "a proteção do fraco pelo forte". Nisso continuavam a lógica estamental, com o Estado substituindo o senhor patriarcal no "proletariado" ao "povo". Respondiam ao dilema político com políticas sociais em vez de democracia. Um Estado de bemestar é o caminho positivista para evitar as rupturas revolucionárias (ALONSO, 2002).
\end{abstract}

Conscientes de que a conjuntura social do século XIX não ensejava condições para a inclusão do negro na sociedade industrial emergente, os positivistas defenderam um projeto de incorporação desse proletariado ex-escravo na sociedade moderna, segundo os preceitos de Augusto Comte, como meio de protegê-los da mercantilização capitalista do trabalho que fatalmente os colocaria, sob novas táticas e engrenagens, numa outra condição subalterna degradante. É dessa forma que o positivismo, embora 
Comte não elabore uma teoria econômica propriamente dita, se consagrou como o precursor do Estado social brasileiro. Ribeiro ressalva o esforço dos positivistas, principalmente Teixeira Mendes, em instituir uma legislação trabalhista para reorganizar a indústria e o serviço doméstico com o fim da escravidão. $O$ projeto assegurava a regulação social do trabalho com salário, número de horas de trabalho, descanso semanal, férias, aposentadoria, criação de escolas de instrução básica, entre outros (RIBEIRO, 2012). É oportuno inserir a observação de Eric Hobsbawm (1988) quando afirma que o positivismo de Comte figurou uma doutrina modernizadora que inspirou os governos do Brasil e do México no século XIX, pois combinava a fé na ciência e na modernidade com o equivalente secular religioso, o progresso não democrático e um planejamento sócio-econômico vertical. Este pensamento persuadiu as elites modernizadoras do poder para que esses países latinos alcançassem a marcha prevista para o século XX. A grande mazela deixada pela mentalidade autoritária positivista foi precisamente o temor ao empoderamento da população diante dos impasses sociais, propondo em seu lugar soluções de caráter paternalista e autocrático.

Na esfera política, os positivistas ortodoxos sustentaram um bom governo de moralidade pública por meio de uma ditadura sociocrática em que a transparência das contas públicas estatais e a completa liberdade de expressão drenariam a voz do povo diretamente para o ditador encarregado do executivo. Ocorreria um modo de participação política direta da população por meio de plebiscitos ou aclamações populares, substituindo e reduzindo a representação do parlamento, cuja função seria estritamente orçamentária com a fiscalização das despesas e dos impostos (ALONSO, 2002). Com isso, podemos inferir que o positivismo no Brasil assumiu um viés bem mais humanista que o "cientificista e mecanicista" ao qual Sousa Santos (2009) se refere.

Por fim, devemos salvaguardar que tanto os liberais como os positivistas, apesar de suas diversificações grupais, advogaram em consenso o reformismo social em detrimento da revolução. Segundo Alonso (2002), os intelectuais da geração 1870 eram contestadores, não revolucionários. Marginalizados pela elite saquarema, esses membros se apresentaram como os novos mediadores entre a sociedade moderna e as instituições políticas. Continuavam o elitismo da sociedade imperial ao se intitularem como os portadores de uma política científica capaz de regular e regrar 
hierarquicamente a participação popular. Dessa forma, a ordem saquarema deveria ser extinta por ter a escravatura como paradigma de distinção social, mas a ordem em si mesma com sua estrutura hierárquica deveria ser mantida. A solução era inserir uma reforma na estrutura social com novos princípios de organização (ALONSO, 2002).

Mas devemos ressalvar que, apesar desse conservadorismo latente do liberalismo político e do positivismo, os traços emancipadores que essas vertentes introduziram como rumo social-desenvolvimentista foram resolutamente abortados pelas elites oligárquicas que sucederam na República Velha. Conforme Fernandes (2008), os anos posteriores à Abolição foram extremamente penosos para as populações negras nas cidades, apesar de toda expectativa humanitária dos ideais abolicionistas. Após a destruição da ordem escravocrata, os negros foram projetados numa arena de competição aberta com os brancos, tendo que ocupar as posições mais subalternas e mal-remuneradas na divisão do trabalho. Quanto à democracia representativa e ao Estado de proteção social, levantados respectivamente por essas correntes de pensamento, Paim (1987) aborda a permanência da política censitária no liberalismo brasileiro, iniciada em 1824 e continuada após a Lei Saraiva de 1881, que impedia o voto aos analfabetos e regulava de forma bem restrita a representação das minorias. Ribeiro (2012) destaca a importância do projeto trabalhista do positivista Teixeira Mendes, elaborado meses após a Abolição, que inseria as reivindicações dos trabalhadores urbanos, mas que foi descartado pela política financeira de Rui Barbosa.

Tais considerações acerca dessas perspectivas frustradas do liberalismo político e do positivismo nos levam a considerar um ponto bem nevrálgico da influência do pensamento abissal levantada pela sociologia de Sousa Santos: as linhas abissais do pensamento ocidental permanecem nas prerrogativas dos povos latinos não apenas, conforme diz o autor, porque essas nações ainda não automatizaram um pensamento pós-abissal baseado na conjunção de saberes e experiências pluralistas (SANTOS, 2009), mas também devido ao arrefecimento ou aborto das propostas progressistas que as vertentes eurocêntricas introduziram num momento crucial de mudança de conjuntura sócio-política de um determinado país. No caso do Brasil, a passagem do regime monárquico para o republicano eclodiu na germinação de ideais liberais e positivistas que apontavam para a reformulação de uma nova ordem social com políticas inclusivas 
que ofuscariam qualquer tentativa revolucionária. Uma vez sufocados a democracia representativa e o Estado de proteção social por grupos dominantes da República Velha que substituíram a elite saquarema mantendo a exclusão social, esses projetos embora oriundos de uma elite intelectual, tornam-se com o desdobramento dos ciclos republicanos, pedras angulares nas lutas políticas para a construção de uma sociedade mais justa e inclusiva.

Com base nessa análise, a dificuldade de erigir um pensamento social brasileiro decorre tanto da busca de uma modernização nacional arraigada nos modelos sóciopolíticos europeus, já que durante séculos predominou uma narrativa eurocêntrica que colocava na invisibilidade os povos latinos e orientais no que tange à formulação de um pensamento próprio, como das tentativas de compreensão dos intelectuais brasileiros diante dos impasses que a sociedade brasileira encontra para estabelecer em seu seio um projeto modernizador e includente. Tal esforço em assimilar os problemas sociais impeliu, ao longo dos períodos republicanos, gerações de intérpretes como Caio Prado Júnior, Oliveira Viana, Sérgio Buarque de Holanda, entre muitos outros, a considerar primeiramente os efeitos deletérios resultantes do tipo de formação colonial, assim como os insucessos das elites intelectuais em reformar politicamente o país. Por isso, esse posicionamento intérprete da intelectualidade brasileira que consiste na ininterrupta crítica às limitações da sociedade perante um patamar ideal de modernização tolhe as possibilidades de elaborar uma epistemologia que lhe seja peculiar.

\section{Considerações finais}

Dado o desenvolvimento exposto, podemos concluir que a experiência da geração 1870 sinaliza o potencial pragmático da intelectualidade brasileira em apostar nas propostas sociais decorrentes de um movimento político-intelectual inspirado no liberalismo político e no positivismo no lugar de erigir uma teoria própria do Brasil. Se analisarmos a experiência histórica da geração 1870 à luz da sociologia de Boaventura de Sousa Santos que ao dialogar com as teorias pós-coloniais, denuncia a prevalência do pensamento abissal que impede a possibilidade dos povos da América do Sul 
conceberem sua própria epistemologia para que assim possam se tornar co-presença e encarar os grandes centros ocidentais numa relação mais igualitária, constataremos que a própria incursão das matrizes desse pensamento já denota complexidade.

No caso do Brasil, percebemos que o ingresso do liberalismo político e do positivismo, na obra de Angela Alonso, desvelou uma dinâmica no próprio processo de assimilação. Desse modo, a intelectualidade brasileira, no século XIX, foi impulsionada pela exclusão social da elite imperial e, prosseguindo tal prerrogativa pragmática, preferiu antes investir numa projeção política que criar sociologias nativas, embora possamos considerar que determinados membros da geração 1870, como Joaquim Nabuco, Sílvio Romero, Tobias Barreto, Miguel Lemos e Raimundo Teixeira Mendes, conforme suas trajetórias, mostraram aspirações acima do pragmatismo e quiseram deixar um legado intelectual e simbólico. O fator mais nevrálgico, não explorado pelo texto de Sousa Santos, deve-se precisamente ao fato de que as propostas socializantes do liberalismo político e do positivismo, que são expressões da mentalidade abissal, por mais que salvaguardassem um modelo conservador e hierárquico, foram frustradas pelas novas elites sócio-econômicas que sucederam ao regime monárquico no Brasil, o que fez com que elas fossem gradativamente incorporadas pelo coletivo político da população. Basta lembrar que o Estado social apregoado pelos positivistas germinou nos períodos da Era Vargas e da República Populista, e a ampla representatividade sustentada pelos liberais só foi confirmada na Constituição de 1988. Não se pretendeu aqui fazer um contraponto à sociologia pós-colonial de Boaventura de Sousa Santos, apenas problematizar a forma como as matrizes do pensamento abissal foram assimiladas pela intelectualidade brasileira do século XIX, ressaltando que o ingresso tanto do liberalismo político quanto do positivismo não foi um processo passivo desprovido de uma dinamicidade.

\section{Referências}

ALONSO, Angela. Ideias em Movimento: A Geração 1870 na Crise do Brasil-Império. São Paulo: Paz e Terra, 2002. 
BARROS, Roque Spencer Maciel de. A ilustração brasileira e a ideia de universidade. São Paulo: Convívio, 1986.

BHABHA, Homi. "A Questão do "Outro": diferença, discriminação e discurso do colonialismo". In: HOLLANDA, Silvia Buarque de (org.) Pós-Modernismo e Política. Rio de Janeiro: Rocco, 1992, p. 177-203

CONNOR, Steven. Cultura Pós-Moderna: Introdução às Teorias do Contemporâneo. São Paulo: Edições Loyola, 2000.

FANON, Frantz. "Sobre o pretenso complexo de dependência do colonizado". In: Pele negra, máscaras brancas. Salvador: EDUFBA, 2008, p. 83-102

FERNANDES, Florestan. "Do Escravo ao Cidadão”. In: BASTIDE, Roger \& FERNANDES, Florestan. Brancos e negros em São Paulo. São Paulo: Global, 20o8, p. 27-90

HALL, Stuart. Da Diáspora: Identidades e Mediações Culturais. Belo Horizonte: Editora UFMG, 2009.

HOBSBAWM, Eric J. A Era dos Impérios 1875-1914. Rio de Janeiro: Paz e Terra, 1988.

LINS, Ivan Monteiro de Barros. História do Positivismo no Brasil. São Paulo: Companhia editora Nacional, 1967.

MATTOS, Ilmar Rohloff. O Tempo Saquarema: a formação do estado imperial. São Paulo: Hucitec, 2004.

PAIM, Antonio. História das Ideias Filosóficas no Brasil. São Paulo: Convívio, 1987.

RIBEIRO, Maria Thereza Rosa. Controvérsias da questão social: liberalismo e positivismo na causa abolicionista no Brasil. Porto Alegre: Zouk, 2012.

SAID, Edward. Orientalismo: o Oriente como invenção do Ocidente. São Paulo: Companhia das Letras, 2019.

SANTOS, Boaventura de Sousa. "Para além do Pensamento Abissal: das linhas globais a uma ecologia dos saberes”. In: SANTOS, Boaventura de Sousa \& MENESES, Maria Paula. Epistemologias do Sul. Coimbra: Edições Almedina, 2009, p. 23-72

SPIVAK, Gayatri Chakravorty. Pode o subalterno falar? Belo Horizonte: Editora UFMG, 2010. 